\title{
An African hermeneutic reading of Luke 9:18-22 in relation to conflict and leadership in pastoral ministry: The Cameroonian context
}

\begin{abstract}
Authors:
Mbengu D. Nyiawung ${ }^{1}$

Ernest van Eck ${ }^{1}$

Affiliations:

${ }^{1}$ Department of New

Testament Studies, University

of Pretoria, South Africa

Note:

This article is an abstract from Rev. Dr Mbengu D. Nyiawung's $\mathrm{PhD}$ thesis 'Who is the Christ? Leadership and conflict in Luke 9:18-22: A social scientific and narratological analysis from an African perspective', submitted and defended in 2010 in the Department of New Testament Studies, Faculty of Theology, University of Pretoria, with Prof. Dr Ernest van Eck as supervisor. Some parts of the article have also been published in the Journal of the Presbyterian Theological Seminary Kumba, Voices from Kumba, as 'An African hermeneutic reading of Luke 9:18-22 in relation to conflict and leadership', 2010, Volume, 3, 69-85.
\end{abstract}

Correspondence to: Mbengu Nyiawung

Email:

revmbengu@yahoo.com

Postal address:

PO Box 590, Kumba,

Republic of Cameroon

Dates:

Received: 26 Nov. 2011

Accepted: 07 July 2012

Published: 04 Mar. 2013

How to cite this article: Nyiawung, M.D. \& Van Eck, E., 2013, 'An African hermeneutic reading of Luke 9:18-22 in relation to conflict and leadership in pastoral ministry: The Cameroonian context', HTS Teologiese Studies/Theological Studies 69(1), Art. \#1201, 9 pages. http://dx.doi.org/10.4102/ hts.v69i1.1201

Read online:

Scan this QR
code with your
smart phone or
mobile device
to read online.

The practice of ministry is an intricate issue which involves the combination of individual efforts from diverse backgrounds. This diversity has been a breeding ground for conflict between the clergy and all the stakeholders involved in parish administration. This article attempted to highlight some of these conflicts, using the Presbyterian Church in Cameroon as a case study. The approach employed is an African hermeneutic reading of Luke 9:18-22 in which the clergy's leadership has been likened to that of Jesus. The presence of many distracting agents did not perturb Jesus' ministry instead, he remained focused. Conclusively, it is observed that the clergy often face conflict within the ministry because they ignore the fact that (1) they are expected to know their mission better than anyone else; (2) the diverse backgrounds of their followers are potential causes of conflict; and (3) there are several distracting agents within the ministry. In short, Jesus' model of conflict management is recommended to the clergy for an effective pastoral ministry.

\section{General introduction}

Nyiawung (2010a:191-204, 276-290) has remarked that Luke 9:18-22 occupies an important place within Luke's gospel with regard to Jesus' leadership approach and the conflicts that animated his relationship with his contemporaries. Read from the perspective of this approach, Luke 9:1822 challenges modern understanding and application of the relationship between leaders and followers. It equally reflects on how people respond to the question of Jesus' identity or that of the clergy, with reference to their responsibility towards their followers. An African hermeneutic reading (AHR) of this passage is therefore a reflection on how Jesus' leadership approach, as well as the conflict that he faced, challenges the clergy in their day-to-day activities. It focuses on the clergy because as witnesses to what Jesus said and did (Lk 24:46-49), they have assumed the legacy of leadership in the area of the pastoral ministry.

Hence, this article is a study from the perspective of the clergy's relationship with the congregation, the elders and other stakeholders involved in ruling the society: the executive, the legislative, the judiciary and the religious. ${ }^{1}$ More specifically, it is an AHR with focus on the practice of the pastoral ministry within the Presbyterian Church in Cameroon (PCC). ${ }^{2}$

This study consists of three main sections. Firstly, attention is given to the definition of terms and the practice of ministry within the Presbyterian Church in Cameroon (PCC). The first section also includes an excursus on the African hermeneutic approach. Secondly, an AHR of Luke 9:1822 is applied to liken Jesus' relationship to the crowds, the disciples and the Jewish authorities (referred to in Lk 9:18-22) to the clergy's relationship with the parishioners; the parish elders and the ruling elite. Finally, Luke 9:18-22 is applied to the general practice of the pastoral ministry.

\section{A definition of terms and a description of the pastoral ministry in the Presbyterian Church in Cameroon \\ Definitions}

The epithet African relates to a vast continent with a great diversity in terms of peoples, culture, beliefs and language. 'Africa' is used in this article with reference to the area of Africa situated south of the Sahara. This area more or less shares the same social, economic and political problems

\footnotetext{
1.The word clergy and pastor will sometimes be used interchangeably. They both refer in general terms to those who take care of God's sheep.

2.The hermeneutic reading of Luke 9:18-22 is not exclusively about church leadership. Church leadership has been chosen as a case study so as to elucidate the types of relationships that involve leaders and their followers. Since followers and leaders constantly influence each other in the exercise of their various functions, all that is said of church leadership in this article is applicable to secular leadership as well.
}

Copyright: (c) 2013. The Authors, Licensee: AOSIS OpenJournals. This work is licensed under the Creative Commons Attribution License. 
that are common to almost all developing countries. Hence, the term 'Africa' could equally stand as a representation of the context of developing countries communities.

Many scholars do not seem to agree on the definition of hermeneutics (cf. Porter \& Clarke 1997:4). This ambiguity is probably due to the fact that the term hermeneutics has a close and synonymous relationship with other terms like 'exegesis' and 'interpretation'. However, hermeneutics is the art of reflecting on how explanation and understanding of texts can be realised and transformed into an existential event for readers and listeners (see De Wit 2009:5; Van Eck 2010:80). Hermeneutics therefore involves understanding and appropriation for the purpose of interpretation and application.

The AHR is an epistemological approach which aims at reducing the historical, cultural and social gaps between the contexts of New Testament texts and the African context through the use of models that are appropriate to the African context. In this process, the (African) reader plays a fundamental role of arbitration in bringing the biblical text as well as its contexts into conversation with the African context. Hence, the African hermeneutic approach to New Testament texts (e.g. Lk 9:18-22), aims at inspiring other developing countries to be aware of the fact that they are potential contexts for the study and practice of theology. This approach therefore considers the context of African readers or audience as an inescapable point of departure to effective exegesis in Africa.

In this article, Luke 9:18-22 is therefore reread with the lenses of leadership and conflict inherent in the pastoral ministry, with focus on the clergy's role in the PCC.

\section{Excursus: African biblical approach}

In the field of biblical interpretation, the African hermeneutic approach (AHA) focuses on the context of the audience, making use of the results from other methods of exegesis and applying them to the realities of the African context. It takes its roots from the contexts of biblical writings, before emphasising the relevance of the 'message' to the African people in their context. It is about how issues raised in the Bible can be interpreted and addressed within the social, cultural and religious context of Africa. Just as the etic ${ }^{3}$ reading of biblical texts is facilitated through a study of a 1st century Mediterranean world view, an African hermeneutic reading is possible only when the study of the African context is taken seriously (Ukpong 1994:40).

Secondly, it is a way of rereading; it considers biblical texts as a challenge to African theologians (especially), whose task is to seek solutions to the various problems that plague African societies (Nyiawung 2010b:69). It is a critique, both of African theologians and the nature of theological training

3 According to Nyiawung and Van Eck $(2012 \cdot 2)$ the term etic relates to the word 'phonetics' (the science of speech sounds). It has to do with how an external "phonetics' (the science of speech sounds). It has to do with how an external investigator classifies systems different from his or her own. It refers to an analysis from an outsider's point of view and makes use of theories or models formulated by the exegete in order to facilitate understanding (cf. Van Aarde 2006:367). offered in most sub-Saharan African theological institutions. In most cases, the curriculum is still alien to the context of study. The AHA is therefore an invitation for the retraining and empowerment of African exegetes.

Thirdly, the AHA intends to create a dialogue between the text and the African context through the process of appropriation. It aims at appropriating texts before interpreting and applying them to the African context. In this process, exegetes encourage the audience to make scripture part of life, reading it in a way that brings about personal and social transformation. It is only when people start considering Bible stories as real stories that address them in their context that the real process of appropriation begins. West (2009:51) agrees that effective biblical interpretation in Africa must rest on the biblical text, the African context, and appropriation. Thus, the AHA is also about the contextualisation of biblical texts because it seeks to make the existential realities of Africa the subject of interpretation.

Finally, the African context seems to share the same social systems with the context of biblical texts. The AHR therefore functions on the premise that there exist some African social values, social institutions, societal arrangements and cultural dynamics which are useful in the understanding and interpretation of biblical texts. Therefore, there exists the need to identify and verify relevant and acceptable African models and theories that can enhance understanding and application. Diachronically, the AHR uses models and theories in order to better understand, assimilate and interpret biblical texts in the African context. In this way, the exegete escapes from the dual errors of anachronism and ethnocentrism. Synchronically, the AHR respects the autonomy of texts as vehicles of social communication and of social interaction.

The AHR does not claim to be the best approach to biblical interpretation. Rather, it is simply an alternative approach that enriches exegetes (African) in their quest to read and understand what biblical texts actually communicate to their own contexts.

\section{Pastoral ministry in the Presbyterian Church in Cameroon}

The Presbyterian Church in Cameroon (PCC) is the historical and constitutional successor of the Basel Mission from Switzerland, established in Cameroon in 1886. It gained independence on 13 November 1957, and since then has operated as an autonomous religious institution. According to its Constitution (PCC 1998:1), she maintains the spiritual and theological continuity of its predecessor and upholds the Reformed tradition. Her mission is 'to proclaim the Good News of God through Jesus Christ, in word and action' (PCC 1998:3).

The name Presbyterian comes from the Greek presbyteros, meaning elders or rulers of the people. The PCC is thus a church of elders because it believes in the priesthood of all believers (cf. Ex 19:4-9; 1 Pt 2:9). This means that anybody 
(ordained or not) can serve as a leader within any setting. As a result of this, ministry in the PCC is shared ministry between the teaching elders (the clergy), and the ruling elders (the laity). The terms 'teaching' and 'ruling' appear to be misleading because they indicate a demarcation in terms of leadership functions between the clergy and the laity. Effectively, there exists a couched delineation between the clergy and the ruling elders, which is in itself a source of conflict. However, such demarcation should be understood from the perspective of shared ministry as explained above. ${ }^{4}$ As a shared ministry, both the clergy and the elders have pastoral oversight of the congregation (Presbyterian Church in Cameroon 1995:4). It is in this light that the term 'pastoral ministry' should be understood to mean the fusion of the ordained ministry with the lay ministry for the purpose of nurturing and guidance of God's people within the church.

The practice of ministry in the PCC is inspired by Paul, who recognised the place and the role of authorised elders as administrators within local churches (Ac 14:23). Consequently, the meaning of the word ministry in this study is not reduced to the activity of the clergy alone. In a broad sense it defines and explains the relationship between the teaching elders and the ruling elders and the way they each use their respective offices to influence their communities. Nyiawung (2009:21) agrees with Krass (1992:2) that pastors and elders are expected to influence the spiritual lives of congregational members through their daily service. Thus, ministry in the church means shepherding (Skreslet 2006:157). ${ }^{5}$ In this sense, pastoral ministry would refer to the way through which the clergy and the laity influence each other in making known the question of Jesus' identity manifested in his life and ministry. In what follows, the teaching elders will be addressed as 'clergy', whilst the ruling elders will be identified as 'elders'.

From the viewpoint of functions, it has already been mentioned that the very nature of the distinction between the clergy and the laity is in itself a breeding ground for conflict. Leadership involves power and authority. In most cases, sporadic conflicts occur between the clergy and the elders as to who has the 'power' to command. However, insofar as spiritual matters are concerned, elders recognise the clergy as their 'spiritual leaders'. The clergy are transferred to local congregations by church hierarchy, whilst elders are elected by the congregation from within its membership. Elders are further described as 'helpers' to the clergy (PPC 1984:93). This description implies that the clergy are 'leaders', whilst elders form part of the 'followers'. However, what is required from both is collaboration and humble service (Lk 22:24-27), in the form of 'ministry' (Krass 1992:1).

4.Grundy (2003:4) argues that even though orders of priests and bishops (the clergy) were not part of New Testament times, they developed a significant place as teachers and guardians of the faith. In this study the teaching and guardian role is considered as the leadership (spiritual) assigned to the 'trained' elders, as opposed considered as the leadership (spiritual) assigned to the trained elders, as opposed to the role of lay elders who still expect nurturing, care and further training from church ministers. Having acquired basic training from the clergy, they both have the responsibility to offer up the cares and the concerns of their community in praye
and in worship. This in essence, is the meaning of shared ministry.

5.The same imagery of ministry as shepherding is used by Jesus (Jn 21: 15-17) and Pau (Ac 20:28-29), with reference to the leaders' stewardship towards their followers.
Cameroon is a secular state. For this reason, the clergy are requested to abstain from partisan politics (Nyansako-niNku 1993:16; Botman 1997:74). However, they remain the representatives of the values, principles and presence of the reign of God. In this light, De Gruchy (1997:93-94) argues that for the church's prophetic role to be effective, its clergy is expected to maintain a critical distance from both political and civil society. Nonetheless, Christianity permeates a bulk of the State's affairs because most of government agents, who are Christians, influence political actions through their diverse services. Notwithstanding, the Cameroon government sometimes influences the clergy's activities through threats and censorship. This usually happens when the Church becomes vocal on issues of injustice. Nyiawung (2010b) reports that:

$[M]$ any clergy have been incarcerated and/or subjected to several hours of questioning because they are considered as opponents to the government. They have been reminded on several occasions on where their influence ends, and this will be in the Church. Many politicians know Paul's instructions for submission to government authorities in Romans 13:1-7 by heart, but (quite often), they ignore government responsibilities towards the welfare of citizens. (p. 7)

As a result of such influence, the clergy has sometimes lost its prophetic voice for the sake of security. This conflict situation stifles the clergy's ambition to exercise leadership freely.

The PCC does not have an episcopal form of church government. Its hierarchy, through the highest governing body - the synod - headed by the moderator, defines priorities for the entire church and expects all its members to follow. Hence, each clergy serving as the moderator's representative ensures the implementation of all synod decisions in their areas of work. This role sometimes creates dissonance within the clergy, especially when some of these decisions become incompatible with biblical demands. This situation sometimes causes friction between the clergy and the hierarchy, resulting in suspensions and dismissals.

\section{African hermeneutic reading of Luke 9:18-22}

\section{Luke 9:18-22: The clergy and congregational members ('the crowds')}

Luke 9:18-22 is a transitory passage in Luke's Gospel that concludes Jesus' Galilean ministry and inaugurates the Jerusalem ministry (Nyiawung 2010a:64). The narrative consists of a conversation between Jesus and his disciples on the subject of his identity. The narrative opens with a question which investigates and explains Jesus' relationship with those who thronged him: 'Who do the crowds say that I am' (Lk 9:18b). In Luke, so far, Jesus had gained much reputation through teaching and preaching (Lk 4:43); through miracles of healing ( $\operatorname{~k~4:38-41),~raising~the~dead~}$ (Lk 7:14-15; 8:53-55); exorcism (Lk 8:26-39; 9:37-43; 11:1423) and providence (Lk 9:10-17). These activities seemed to have created a false impression for the crowds, influencing them to construct an image of Jesus that fitted their personal 
expectations. Jesus understood that his popularity was understood and interpreted in terms of the social needs of the crowds, rather than in terms of his identity and mission. Their speculations, as echoed by the disciples, effectively agreed with Jesus' suspicion of false loyalty. Even though the crowds had a glimpse of his identity, they rightly awarded legitimate praises with wrong intentions. This picture depicts the image of the PCC clergy in a context where social, economic and political crises have crippled the society. It is in this situation that the clergy are looked upon to for directives and guidance. ${ }^{6}$

The impact of the clergy within the congregation is encapsulated in the ministry of preaching, teaching and healing (cf. Lk 9:1-6). Just as the crowds had an influence on Jesus' mission, congregational members and the public at large play a vital role in the clergy's activities. Although they are a source of encouragement, their attitude can mislead the clergy. One such example is the attribution of ambiguous titles, such as prophet and saviour, which becomes an opportunity for self-aggrandisement and pride (cf. Lk 11:43; 12:1; 20:46). Though Jesus respected the speculations from the crowds, he did not claiming to be Elijah, John the Baptist or one of the prophets of old.

Another method of false loyalty is by way of granting gifts to the clergy. During his ministry Jesus gained from the hospitality of Martha (Lk 10:38-42). Some of those who received healing either served $(\operatorname{Lk} 4: 39,9: 38)$ or followed him (Lk 8:2). He also agreed that 'the labourer deserves his wages' (Lk 10:7). By implication, Jesus recognised the awarding of gifts as a sign of solidarity, hospitality, sharing and gratitude (Lk 9:3-6; Lk 10:8-10). In the early church, gift offering was misinterpreted and misused by itinerant leaders as a means of exploitation (Horrell 1999:311). Today, the clergy have been disoriented and manipulated through the awarding of gifts. Also, Jesus disagreed with leaders who are lovers of money (Lk 16:14) and opposed the use of his name as a means of exploitation and extortion (Lk 20:46-47). He equally castigated the misuse of the ministry for personal enrichment (Lk 19:45-48).

As a new phenomenon in the PCC today is that congregational members applaud the clergy after delivering a sermon. Although this attitude seems a sign of approval and appreciation, it remains a dangerous method of legitimising leadership. It either implies acceptance or rejection, depending on the intentions of those who clap. This practice creates dissonance amongst the clergy which, if not well managed, could lead to arrogance and self-proclaimed piety. It also projects the clergy's ego at the expense of Christ's identity. In congregations with more than one pastor, this practice creates tension between the pastors and resenting camps of preference between congregational members. Jesus is clear on the matter that every kingdom divided against itself cannot stand (Lk 10:17).

6.The clergy play a fundamental role in education in Cameroon. In response to circulated rumour concerning an eminent parousia a few years ago, an old mother exclaimed with conviction: 'If it were a true story, the pastor would have informed us last Sunday.'
Some congregational members are often overwhelmed when a clergy from their ethnic origin is posted to their congregation. As an underlying intention, they expect to benefit some special favour from the clergy because of their shared identity. They become friendly and exhibit false love, solidarity and sharing. Jesus was conscious of the composition of the crowds that followed him. Consequently, clergy who fall victim of ethnic enticement automatically create conflict within the congregation and build boundary markers of segregation, suspicion and hatred.

There is a need for the clergy to be observant in order to detect the intentions of 'the crowds', who sometimes pretend to know the clergy's functions better than they themselves. Suspicious and unflinching loyalty from congregational members must call for self-evaluation and investigation. The crowds that followed Jesus were a force to be reckoned with (cf. Lk 19:47-48; 20:6, 19). Their attempt to derail him failed because he knew his mission, and so remained focused and unperturbed. It is incumbent for the clergy to strive towards accomplishing the legacy that was laid down by Jesus.

Most Cameroonian believers have become passionate and demanding. This justifies the ongoing spiritual search that presently sweeps through the continent. ${ }^{7}$ As a result, many people look up to the clergy with lots of expectations. This happens especially with those who have experienced Jesus' presence in their lives in various ways. Testimonies of such experiences have thus occupied an important place within worship services. In this situation, the clergy's responsibility is to channel and reshape these spontaneous conceptions into acceptable confessions of faith. It is also their responsibility to assist believers to grow from their perceptions of what Jesus does to a concrete knowledge of who he is. Failure to do so, the clergy continue to cajole believers with half-baked and prosperity teaching which only form 'skin Christians'. When such believers are faced with unexplained difficulties, they readily return to their traditional beliefs.

Jesus' dialogue approach, as well as his response to the question surrounding his identity, reflects the manner in which Christian teaching should to be carried out by the clergy. They indicate that no one holds the monopoly to the response to Jesus' question (cf. Lk 9:18). It challenges the way of teaching catechetic classes and Bible studies in congregations. Nowadays neophytes can no longer parrot Peter's response: Jesus 'is the Christ of God' (cf. Lk 9:20), without knowing the implications of such response. They must be enabled to discover who Jesus is, and what he does to humanity. It suffices to empower the Christians spiritually by involving them in the reading and understanding of scripture. In fact, people must be taught and empowered to interpret the signs of the time by themselves and to grow out of ignorance (Artherton 1994:14). Each person has an experience to share and a contribution to make with reference

7.The growing number of religious gatherings in Cameroon testify such spiritual urge In fact, churches are sprouting up daily. People keep streaming to neighbouring Nigeria in search of spiritual enrichment and prosperity. Others have developed Nigeria in search of spiritual enrichment and prosperity. Others have developed
much interest in faith-extending gadgets such as 'holy water', rings, crosses and anointing oil. 
to the question of Jesus' identity. People know the truth of the gospel when they have been given the possibility to wrestle with it. Consequently, the clergy is called upon to serve as facilitators or discussion leaders, and not as commanders or masters (Taylor 1994:1). By truly executing their leadership function in the light of dialogue, teaching, feedback and empowerment, the clergy curb, minimise and avoid conflict.

\section{Luke 9:18-22: The clergy and parish elders ('the disciples')}

From Luke 9:18-22 it is clear that Jesus, rather than rally the crowds to find out what they thought of his identity, preferred to launch an inquest towards his closest followers, the disciples. From their response he seemed to have been motivated to ask about themselves: 'But who do you say that I am' (Lk 9:20). This discussion came at a crucial moment of Jesus' ministry. Firstly, it concerned his growing popularity, fostered by his activities of preaching, teaching and healing. Secondly, it cleared away the misconception inherent in this popularity as already exhibited in Nazareth (Lk 4:22-30). Thirdly, it was about the ambiguous attitude of the disciples that seemed to have existed from their calling (Nyiawung \& Van Eck 2012:1). Fourthly, it concerned the antagonism that Jesus already faced from the religious elite. Fifthly, it was a check of information as he concluded his Galilean ministry. Finally, Jesus wished to communicate his identity and its implications to his followers so that they would not remain unaware of the events that would befall him. It was an important moment of sharing because the disciples were to become legal successors of Jesus' missionary vision.

In a congregational setting, the discussion in Luke 9:18-22 insinuates the nature of the relationship between the clergy and their 'collaborators': the elders. Just like the disciples, who followed Jesus, church elders are the clergy's helpers since they complement each other in ministerial duties within the congregation. The variety of their respective professional backgrounds (just as it was the case with the disciples) accounts for the rich experiences that they possess. Coming from within the congregations, they are closer to the grassroots than the clergy. In their daily routine the clergy are often engaged in sacramental, administrative, evangelistic and pastoral functions, all of which they cannot do alone (Taylor 1994:2). Thus, the contribution of parish elders becomes imperative because they give spice to the clergy's activities with insights gained from their professional backgrounds. It is fruitful when the clergy use the elders to evaluate their ministry. This methodology assures the elders of the validity of their contributions as the clergy's daily companions. ${ }^{8}$

Jesus' leadership style derived from this dialogue (Lk 9:18-22) is an important inspiration to the clergy. Jesus challenges the clergy to become more effective in leadership training. Even though most elders are leaders in other professions, they still need training on how to deal with spiritual issues.

8.This approach is different from the normal administrative session meetings that the clergy often convene within the congregation.
Leadership training offered by the clergy is modelling that of Jesus because it incorporates courage, patience, endurance, compassion and understanding. Despite the wayward attitude of the disciples, Jesus neither rejected nor despised them. Leadership training equips elders and further empowers them to function well in the absence of the clergy (Krass 1992:104). As compared to the elders, the clergy know their mission better because they have been called and trained for that purpose. It is therefore incumbent upon them to constantly transmit the content of their ministry to the elders through training sessions. This approach enables the elders to 'know and understand' (see Lk 9:13; 9:45, 49), if not, they will guess, doubt, misunderstand and misinterpret (see Lk 8:25b). Ignorance destroys leadership because it generates conflict, doubts, suspicion and mistrust. One of the best methods of leadership training is empowerment through Bible studies.

The Bible is an essential source of authority and power for an effective Christian leadership. In Bible study classes the clergy enable the elders to understand Jesus' identity as well as what it means for him to be the Christ. Failure to train elders in the understanding of leadership from a biblical perspective contributes in making uninformed leaders who live on speculations. Jesus' dialogue approach educates, equips and enables the clergy to share administrative burdens (Eason 2004:18). This is leadership empowerment through the delegation of power. By delegating power, the leader promotes confidence and love. Jesus constantly assigned his disciples, exposing them to creativity, vision, and confidence in their personal abilities and potentials. The best way to become an effective leader is by executing leadership tasks. The clergy empower their collaborators when they create an appropriate leadership atmosphere.

Leadership empowerment also means that the clergy understand and know their mission in the best way possible. Leaders who are easily swayed by their followers would hardly accomplish their expected mission. Jesus never gave in to the pressure from his disciples, rather, he constantly persuaded them to understand that his leadership was different from that of 'the kings of the Gentiles' (Lk 22:25). According to Jesus, leadership in the church must be void of violence and retaliation (Lk 9:55; 22:51); hatred and ethnic segregation (Lk 8:21); lordship and power (Lk 22:24-26); hypocrisy, pretence, exploitation, extortion and pride (Lk 11:37-52; 12:1; 20:45-47); material and monetary concerns (Lk 9:3; 10:4); fear (Lk 12:4-7, 32-34); hesitation (Lk 14:27-32); and anxiety (Lk 12:22-31). As a replacement, he recommends compassionate leadership, which overcomes all vices (cf. Lk 6:36; see also Lk 10: 25-37).

Prayerful leaders are the most effective leaders. Prayer was a characteristic of Jesus' ministry. In fact, his praying attitude influenced his choice of followers (Lk 6:12-16); facilitated the dialogue concerning his identity (Lk 9:18-22); led to the devil's defeat (Lk 4:1-13); spiced the discussion with Elijah and Moses (Lk 9:28-36); and prepared him for his arrest, suffering, rejection and death, as well as his subsequent resurrection (Lk 22:39-42). 
Firstly, leadership success between the clergy and the elders depends on the level of trust that they accord each other. It is such mutual support which enhances their cooperation. Empowerment and collaboration ensure sustainability, continuity and mutual nourishment. Conversely, leadership tension plays an adverse effect on the ministry as a whole. For instance, the abuse of power associated with incomprehension often creates conflict between the clergy and session members. ${ }^{9}$ In fact, the diverse professional background of the elders is another potential basis for conflict. In order to curb such conflict, Jesus exercised patience and tolerance, teaching his disciples on the importance of their mission. Secondly, friction is inevitable when the clergy fail to delegate or share power with the elders. Thirdly, spiritually weak clergy expose themselves to the caprices and mischief of some elders. Finally, power tussles between the clergy and the elders are a breeding ground for conflicts when power and authority become a substitute to services that they are expected to render.

In a nutshell, the understanding of leadership as service conditions, to a larger extent, the nature of the relationship between the clergy and the elders. In this light, Jesus cautioned the disciples:

The kings of the Gentiles exercise lordship over them; and those in authority over them are called benefactors. But not so with you; rather let the greatest among you become as the youngest, and the leader as one who serves. (Lk 22:25-26)

The practice of ministry in the congregation is smooth when both clergy and elders exercise mutual acceptance, understanding ministry as shared ministry for the service of mankind.

\section{Luke 9:18-22: The clergy and the 'ruling elite'}

The political elite and the church's hierarchy are the two authorities that constantly influence the clergy in their daily mission.

\section{Luke 9:18-22: The clergy and the 'political elite'}

In Luke 9:22 Jesus explained his identity with reference to the outcome of his relationship with the custodians of Jewish society. This account incriminated the elders, chief priests and the scribes as those who would suffer, humiliate, reject and kill Jesus. It provides the false impression that Jesus' report exonerated the Roman political elite, who paradoxically played a key role in the passion narrative. In effect, the Jewish elite did not have the right of killing, unless this was legitimised by the Roman political authorities. By releasing Jesus to be killed (cf. Lk 23:25), Pilate and Herod simply joined the Jewish religious elite as opponents to Jesus' ministry.

Although the discussion between Jesus and the disciples concerning the events that had already happened in Galilee, it was essentially focused on what would befall him in

9.According to the Constitution of the Presbyterian Church in Cameroon (1998:18) the Session, which is the executive organ of the congregation, is made up of the clergy
serving within the congregational jurisdiction, the elders and other co-opted church serving within the congregationation.
officers in the congregation
Jerusalem, the centre of political and religious power. It is in Jerusalem that the Jewish religious elite manipulated the legislature and conspired with the executive and the judiciary to kill Jesus. ${ }^{10}$ The resurrection echoed in Luke 9:22 plays several functions: it is a rejection of human ruling and their authority. It is equally a confirmation of Jesus as a true leader and a validation of his ministry. It is recognition of his heavenly reign and an authentication of his ministry. It confirms the fact that leadership needs to grow beyond fear and anxiety (Lk 12:11-12; 21:12). It depicts the atmosphere between the clergy and the governing arm of the society, controlled by the executive, the legislative and the judiciary.

The clergy is the custodian of the principles God's kingdom within the society. They ensure accountability and the process of good governance carried out by the political elite. This is not in any way synonymous to partisan politics. Rather, it is about the clergy's participation in guaranteeing justice and equity. Unfortunately, they often face opposition from political authorities who consider them as intruders. The clergy cannot remain passive in the presence of chaos and misery, and only wait in order to criticise from the pulpits:

Let us not try to server, for they are inseparable, those principles which affect the problems of earth from those which affect the kingdom of heaven. All unrighteous government whatever, all that sets itself against the order and freedom of man, is hostile to Christ's government, is rebellion against Him, in whatever name and by whatsoever instruments it is administered. (Maurice, in Atherton 1994:12)

Ela (1986) also cries out:

As all else is organized to strangle the last hope of justice by torture and repression so as to guarantee the multinationals, the banks, the industries, the mines, and the super-farms the most efficient possible exploitation of the country and the people, the church should once more, by the voice of the bishops [clergy] of Africa, become the voice of the great, silenced masses. (p. 79)

It is the clergy's responsibility to remind the political elite of the various mechanisms which are still deployed in order to suffer, humiliate, reject and kill Jesus. The letter to the Hebrews is clear that any human attitude that is contrary to kingdom principles is like 'crucifying the Son of God all over again and subjecting him to public disgrace' (Heb 6:7). Although the events that befell Jesus are historical, they are still enacted today in various forms. For instance, Jesus is still humiliated and killed through bad policies, misappropriation, extortion, exploitation, injustice and corruption. Jesus' response to the Roman political elite remains an inspiration for the clergy. Although he disagreed with the ruling elite, he did not dismiss the need for rule. He reformed their ruling style through

10.By Roman standards Jesus was not due for capital punishment. Luke records a series of ironies in the process of labelling and disfiguring Jesus. Firstly, the Jewish trial was illegal because Jesus was physically tortured even before the hearing began (Lk 22:63-65). Also, the trial took place, not in the Sanhedrin, but in the high priest's house (Lk 22:54). Secondly, although Jesus was accused of stirring and misleading the people, no one explicitly stood up from amongst the multitude to confirm this charge. Thirdly, Pilate who owned power and authority showed powerlessness and weakness in the face of mob pressure. Fourthly, although he found Jesus innocent, weakness in the face of mob pressure. Fourthly, although he found Jesus innocent, he still wished to chastise him, before releasing him. Fifthly, an insurrectionist is liberated whilst an innocent is convicted for the charge against insurrection. Finally, at four different instances, Jesus was declared innocent (Lk 23:4, 11, 14, 22) by the most authoritative voices of Rome; yet, he was condemned. In terms of Luke's storyline, these ironies rendered the proper reason for Jesus' crucifixion obscure and absurd. However, for Luke's storyplot, Jesus suffered conflict and rejection as a necessity, so as to enter into his glory (Lk 24:26; see also Lk 9:22). 
practical teachings (cf. Lk 20:20-26, 23:3, 23:9). Even though Jesus' attitude was tantamount to causing reformation and transformation on the part of Pilate and Herod, they instead reacted indifferent. Their reaction implied that they still did not understand Jesus' identity and leadership. In the same way, the clergy has the mandate to continue Jesus' mission towards political leaders, even when they seem unmoved. They need to execute their functions without fear, because those who seek to embody the principles of the kingdom in public life are liable to become vulnerable to several attacks (Moltmann 1993:130; Paeth 2008:165).

During the ceremony of institution and induction of the clergy into office in the PCC, they are always cautioned:

Maintain Christian discipline in the authority of the word of God courageously, not being afraid of men but of him only who is able to destroy both soul and body. (PCC 1984:78)

This caution highlights the various spheres of pressures to which the clergy are exposed. Notwithstanding, they are expected to function as yeast, influencing the society in all aspects: the political, the judiciary, the legislative and even the religious.

\section{Luke 9:18-22: The clergy and the 'religious elite'}

In this article, church hierarchy constitutes the religious elite because they are the custodians of the church's tradition. For example, the hierarchy of the PCC defines the goal and the mission of the entire church, based on scripture. The clergy are considered as the direct representatives of the Church within their parishes. Parishes owe respect, honour and loyalty to the hierarchy, whilst the hierarchy responds by way of support and empowerment which they offer through the resident clergy. In Luke 9:18-22, the Jewish religious elite was paradoxically reported as Jesus' principal opponents. Although they all stood for the same cause of interpreting God's holiness, they differed both in their approaches and understanding. Consequently, they refused to legitimise Jesus' identity because he did not operate according to their expectations.

The above description is different from the present day context. Although the Jewish religious elite and Jesus both had a focus on the understanding and interpretation of God's holiness, it was essentially about the reformation of the old religion (Judaism). This justifies why they disagreed at the level of the status quo. Although the religious elite was the custodians of religion, they were not Jesus' direct hierarchy. From an emic perspective, the fact that the Jewish religious elite antagonised Jesus rather than protected him strikes the reader of Luke's Gospel. ${ }^{11}$

At stake in this study is the enmity, the antagonism and the misunderstanding that often exist between the clergy and their hierarchy in the context of applying what God requires of the church. Such enmity is often translated through open

11.The term emic relates with 'phonemics', which are categories of thoughts and explanations of groups that are studied (Elliott 1993:129). It is an anthropological explanations of groups that are studied (Elliott 1993:129). It is an anthropological term which refers to the report of a narration from the point of view of those concerned; that is, the 'natives'. It is a cognitive pattern of what is supposed to happen, including what actually happens (Moxnes 1991:251) confrontation, suspensions, dismissals, accusations and counter accusations and cessations. Jesus did not form a breakaway religion, rather he aimed to reform Judaism from within. He did not dismiss nor sanction religious leaders. Rather, he accepted them, whilst condemning their practices. One of the errors often committed by the church hierarchy is that they frequently evaluate the clergy from the wrong premise. In the PCC, their worth is often considered in terms of numerical growth and financial increase in the parish. Such evaluation accords little or no emphasis on spiritual growth. This was probably the error of John the Baptist when he wished to acknowledge Jesus' presence by evaluating him the wrong way: 'Are you he who is to come, or shall we look for another' (Lk 7:19). Jesus' response implies that success in mission is to be evaluated in terms of its effects, and not in terms of preconceived expectations.

The tension between Jesus and the Jewish religious elite, implied in Luke 9:22, depicts the deviant attitude of the religious elite of contemporary society. Firstly, it is about their attempt to mutilate texts to suit selfish intentions. Secondly, it is a pointer to the misuse of the church for personal enrichment. Thirdly, it is a warning against power tussles amongst the clergy. The untidy relationship between the clergy and the hierarchy is often translated into a fight of personal interest. Finally, it is about the contribution of the clergy by humiliating, rejecting and killing Jesus. In fact, Jesus' reaction might not be different if he came back to physical life. By alluding to his resurrection, he encouraged the clergy to remain hopeful and perseverant when threatened with opposition, ridicule, rejection and death from the political elite and other colleagues.

\section{Luke 9:18-22: The reality of the pastoral ministry}

The conversation between Jesus and his disciples in Luke 9:18-22 is indirectly about the intricacy involved in the practice of the pastoral ministry. Quite often, most leaders count more on their legitimisation by the hierarchy whilst minimising the input of their followers. Jesus benefited from the legitimisation of his father (Lk 3:21-23; 9:35); his followers (Lk 9:19-20); and those who had hitherto been considered as 'outsiders' (cf. Lk 23:47). By inference, leaders have the responsibility of exercising servant leadership to God, to their followers, and to the world at large. Their task is that of explaining the meaning of Jesus' identity as the Christ (Krass 1992:24).

The pastoral ministry is that of risk bearing, suffering and rejection. The clergy are the target of their own following, the political authorities as well as their religious hierarchy. Jesus gave his life as a price of leadership. It is therefore strange when leaders shun conflict instead of embracing it and striving to make use of it. False accusation, demagogy, malice and contempt seem to be some natural traps which the clergy must be ready to confront. Besides, for effective ministry, contemporary clergy need to beware of distracting mannerisms and the misuse of pastoral tiles by elders and 
the congregants. They equally need to let their presentation of Jesus as the Christ march with their own attitude. In other words, their appearance in public must push people to perform acts of repentance in the likeness of Zacchaeus (Lk 19:1-10).

From the above hermeneutic reading of Luke 9:18-22, there are several ways in which leaders approach conflict from a wrong direction. Opposition and conflicts grow increasingly when leaders rather struggle to attract public sympathy or when they look for scapegoats. This approach encourages the creation of factions and dissenting camps. When leaders fight opposition by seceding from the main structure or by dismissing, transferring and rejecting opposing factions, they simply postpone conflict rather face it up front. Leaders further face the worst when they function on the basis of a divide-and-rule system. This type of leadership sows seeds of discord rather than uproots them. Leaders face conflict from the wrong side when they seek support from the secular judiciary without having exhausted biblical prescriptions (Lk 6:37). It is indeed an error to fight conflict and opposition with falsehood, flattery and unrealistic promises or to fall prey to ethnic sentiments. Leadership, opposition and conflicts are inseparable in all spheres of life. They are even crucial in the pastoral ministry where tolerance and acceptance are important virtues. Consequently, opposition and conflict need to be managed with a lot of care and tact when they do arise.

Most often, conflict in leadership arises as a result of factors such as envy, the evil eye, fear, suspicion, mistrust, misunderstanding, ignorance and misinterpretation. One of the best ways to face such conflict is by adopting a compassionate attitude. This refers to compassion for mission as well as compassion for all the stakeholders involved in the leadership process. Inspired by compassion, leaders build viable relationships of understanding through dialogue. This approach enables leaders to respect their collaborators as well as to acknowledge that their opinion is not always final. Each individual within the community has an important role to play (Taylor 1994:1). Dialogue enhances trust, confidence and assurance in leadership. In the dialogue approach, leaders and followers seek mutual legitimisation by investigating and evaluating each other. Through evaluation they are both educated about their deficiencies. Leaders evade or manage conflicts adequately when they treat everyone without bias. Such leaders do not build on falsehood nor do they surround themselves with stooges and sycophants. Above all, in servant leadership, the leaders work and manage opposition and conflict as part of leadership.

\section{Conclusion}

In every society, the relationship between leaders and their followers dictates the atmosphere of the group. The above African hermeneutic reading of conflict and leadership in the pastoral ministry has illumined Luke 9:18-22 in a new way. This approach fulfils one of the aims of contextual exegesis that consists of raising new questions and allowing texts to provide new and relevant responses (cf. Esler 1994:12-13). It also permits the 'new' reader to identify with the text and at the same time appropriate its results in a more convincing manner. Finally, it is an approach that has opened up new perspectives on the text and broken up the myth of established readings resulting from traditional exegetical approaches. In effect, one of the reasons for a contextual reading is an attempt to associate theology with the immense wretchedness and misery which surrounds the society (Stinton 2006:50).

For the African therefore, the issues surrounding the conflicts that animated Jesus' leadership is a source of inspiration to its church leaders so that they may become more effective in their leadership. However, it would be a kind of utopia to think that the study of these conflicts could lead to the discovery of an ideal way of leadership in African churches and societies. This approach of biblical interpretation, however, is at least eye-opener for other contexts to recognise that there is no ideal interpretation of biblical texts. Texts speak to people differently, depending on the various problems that they face on a daily basis. In other words, this article is aimed at empowering theologians of various contexts to practice theology from the perspective of the people, that is, theology in response to the social realities of the community.

The nature of the relationship between the clergy and their collaborators dictates the spiritual pulse of the community. A community that benefits from good leadership is also a community that understands how to manage conflict. Such a community is a potential springboard for spiritual, numerical and financial growth, empowerment and development.

\section{Acknowledgements Competing interests}

The authors declare that they have no financial or personal relationship(s) which may have inappropriately influenced them in writing this article.

\section{Authors' contributions}

The research of this article was done by M.D.N. (University of Pretoria). It is based on M.D.N.'s PhD thesis, submitted in 2010 in the Department of New Testament Studies, Faculty of Theology, University of Pretoria, with E.v.E. (University of Pretoria) as supervisor.

\section{References}

Atherton, J. (ed.), 1994, Social Christianity: A reader, SPCK, London.

Botman, H.R., 1997, 'Towards a world-formative Christianity in South Africa', in M. Guman \& L. Milton (eds.), An African challenge to the church in the 21st century, pp. 72-79, Salty Print, Cape Town.

De Gruchy, J.W., 1997, 'Christian witnessing in a secular state: Rethinking church-state relations in a new democratic South Africa', in M. Guman \& L. Milton (eds.), An African challenge to the church in the 21st century, pp. 86-96, Salty Print, Cape Town.

De Wit, H., 2009, 'Exegesis and contextuality: Happy marriage, divorce or living (apart) together?', in H. de Wit \& G.O. West (eds.), African European readers of
the Bible in dialogue: In quest of a shared meaning, pp. 3-30, Cluster Publications, Pietermaritzburg.

Eason, S.P., 2004, Making disciples, making leaders: A manual for developing church officers, Geneva Press, Louisville.

Ela, J.M., 1986, African cry, Orbis Books, Maryknoll.

Elliott, J.H., 1993, What is social scientific criticism?, Fortress Press, Minneapolis. 
Esler, P.F., 1994, The first Christians in their social worlds: Social-scientific approaches to New Testament interpretation, Routledge, London. http://dx.doi.org/10.4324/ 9780203427729

Grundy, M., 2003, What they don't teach you at the theological college: A practical guide to life in the ministry, Canterbury Press, Norwich.

Horrell, D.G., 1999, 'Leadership patterns and the developments of ideology in early Christianity', in D.G. Horrell (ed.), Social-scientific approaches to New Testament interpretation, pp. 309-337, T \& T Clark, Edinburgh.

Krass, A.C., 1992, Go ... and make disciples, SPCK, Marylebone. (Applied Theology 1).

Moltmann, J., 1993, The way of Jesus Christ: Christology in messianic dimensions, Fortress Press, Minneapolis.

Moxnes, H., 1991, 'Patron-client relations and the new community in Luke-Acts', in J.H. Neyrey (ed.), The social world of Luke-Acts: Models for interpretation, pp. 241-268, Hendrickson Publishers, Peabody MA.

Nyansako-ni-Nku, (ed.), 1993, Cry justice: The church in a changing Cameroon, Presbook Press, Limbe.

Nyiawung, M.D., 2009, Christian leadership from a Cameroonian perspective: An exegetical study of John 13:4 \& 12-15, Lambert Academic Press, Saarbrücken.

Nyiawung, M.D., 2010a, 'Who is the Christ? Leadership and conflict in Luke 9:18-22: A social scientific- and narratological analysis from an African perspective', unpublished PhD thesis, Department of New Testament Studies, University of Pretoria.

Nyiawung, M.D., 2010b, 'The Prophetic Witness of the Church as an Appropriate Mode of Public Discourse in African Societies', HTS Teologiese Studies/Theological Studies 66(1), Art. \#791, 8 pages. http://dx.doi.org/10.4102/hts.v66i1.791

Nyiawung, M.D. \& Van Eck, E., 2012, 'Characters and Ambivalence in Luke: An Emic Reading of Luke's Gospel, Focusing on the Jewish Peasantry', HTS Teologiese Studies/Theological Studies 68(1), Art. \#829, 12 pages. http://dx.doi.org/10.4102/ Studies/Theologit
hts.v68i1.829
Paeth, S.R., 2008, Exodus church and civil society: Public theology and social theory in the work of Jürgen Moltmann, Ashgate Publishing Limited, Farnham.

Porter, S.E. \& Clarke, K.D., 1997, 'What is exegesis? An analysis of various definitions', in S.E. Porter (ed.), Handbook to exegesis of the New Testament, pp. 3-21, Brill, Leiden.

Presbyterian Church in Cameroon (PCC), 1984, Book of divine services, volume II: The initiation rites and ordinances of the Church usually performed within the main service on Sundays, Holy days, and special days, Tron Gebr. KG Verlagsdruckerei, Karlsruhe.

Presbyterian Church in Cameroon (PCC), 1995, Book of Orders: Procedure and Practice of the Church, Presbook Press, Limbe.

Presbyterian Church in Cameroon (PCC), 1998, Constitution, Pressprint, Victoria.

Skreslet, S.H., 2006, Picturing Christian witness: New Testament images of disciples in mission, William B. Eerdmans Publishing Company, Grand Rapids.

Stinton, D.B., 2006, Jesus of Africa: Voices of contemporary African Christology, Orbis Books, Maryknoll.

Taylor, H., 1994, Tend my sheep, SPCK, London. (Applied Theology 2).

Ukpong, J.S., 1994, 'Christology and Inculturation: A New Testament perspective', in R. Gibellini (ed.), Paths of African theology, pp. 40-61, Orbis Books, Maryknoll.'

Van Aarde, A.G., 2006, 'Ebionite Tendencies in The Jesus Tradition: The Infancy Gospel of Thomas, Interpreted from the Perspective of Ethnic Identity', Neotestamentica 40(2), 353-382.

Van Eck E., 2010, Encyclopaedia of the New Testament, unpublished class notes, for ONM 152 and BYA 120, University of Pretoria, Pretoria.

West, G.O., 2009, 'Interpreting the cooperative paradigm in African Biblical scholarship', in H. de Wit \& G.O. West (eds), African and European readers of the Bible: In quest of a shared meaning, pp. 37-64, Cluster Publications, Pietermaritzburg. 